\title{
O sindicalismo docente da educação básica no Maranhão: da associação à emergência do sindicato
}

\author{
Robson Santos Camara Silva \\ Orientador: Prof. Dr. Sadi Dal Rosso \\ Curso: Doutorado em Sociologia \\ Data da Defesa: 17.05.2013
}

sta tese é uma investigação sobre o associativismo e o sindicalismo do-
cente no Maranhão. Diferentemente de outras unidades da federação,
em que a reconstrução do sindicalismo docente já acontece há anos, esse estado brasileiro ainda requer estudos que possibilitem o avanço do conhecimento nesse campo. A pesquisa tem como principais objetivos: reconstruir os processos pelos quais se organizou o magistério maranhense, inicialmente, sob a forma associativa e, posteriormente, na forma sindical, até alcançar o grau de consolidação que a organização exibe nos dias atuais; identificar as organizações de trabalhadores docentes que se formaram ao longo da história da educação maranhense, sua natureza e as razões que conduziram a uma pluralidade de entidades; analisar o associativismo e o sindicalismo enquanto formas de resistência e de ação proativa dos trabalhadores docentes no Maranhão; relacionar o contexto histórico e político com a emergência do associativismo e do sindicalismo do magistério; levantar as principais lutas do magistério maranhense e periodizar sua evolução, bem como analisar as condições atuais do sindicalismo docente maranhense. As condições objetivas e subjetivas de emergência do associativismo docente no Maranhão são condições estruturais que possibilitam o surgimento de associações e sindicatos docentes. O número e a densidade de professores permitiram as trocas de experiências sobre as questões inerentes à profissão, mas que só tiveram efeito a partir da construção de um projeto político que deu vazão às percepções coletivas do mundo do trabalho. Tal realidade não termina em si, mas deve constituir-se para si. A análise do desenvolvimento histórico do associativismo e sindicalismo maranhense demonstra que estes se configuraram em entidades que possuíam o intento de representar todo o professorado (Associação Pedagógica Almir Nina e Departamento maranhense da $A B E)$ e, posteriormente, emergem as formas fragmentadas de representação (Associação de Professoras Normalistas do Maranhão, Sinterp, Sinproesemma e SINDEDUCAÇÃO). A legislação cunhada no regime militar foi responsável por produzir a fragmentação entre os professores públicos e os da rede particular, uma vez que era proibido aos primeiros se organizarem sindicalmente e 
constituírem um sindicato único para todo o magistério de sua região geográfica. Em suma, o associativismo e o sindicalismo docente no Maranhão se desenvolveram em uma sociedade cujo grau de controle se mantinha fortemente ativo e não era possível erigir entidades de defesa de interesses laborais sem fazer mediações com o poder político local.

Palavras-chave: Sindicalismo Docente, História, Sociologia da Educação, TrabaIho Docente. 